\title{
SOSIALISASI 3M DAN PEMBAGIAN MASKER DI PASAR PUCANG, SURABAYA SEBAGAI UPAYA PENCEGAHAN PENULARAN COVID-19
}

\section{W (WEAR MASK, WASH HANDS, WAIT UNTIL OTHERS DISTANCED AT 1-2 METERS) SOCIALIZATION AND DISTRIBUTION OF MASKS AT PUCANG TRADITIONAL MARKET, SURABAYA TO PREVENT TRANSMISSION OF COVID-19}

\section{Avita Fitri Agustin ${ }^{1}$, Anggara Tirta Kusuma ${ }^{2}$, Rommy Sigit Fernanda ${ }^{3}$, Rohmatus Zazilah $^{4}$, Ivangga Dwiputra Leksono ${ }^{5}$, Shindy Septia Dewi ${ }^{6}$, Rachmad Pujo Sakti ${ }^{7}$}

\author{
${ }^{1}$ Fakultas Kesehatan Masyarakat, ${ }^{2,3,4,5,6,7}$ Fakultas Ekonomi dan \\ Bisnis, Universitas Airlangga, Surabaya \\ Email : avita.fitri.agustin- \\ 2018@fkm.unair.ac.id
}

\begin{abstract}
Covid-19 spread rapidly and massively in a short time. Within 1 year, this virus has been able to infect 233 countries in the world. Therefore, it is necessary to make efforts to minimize the spread of Covid-19. One way that can minimize the spread of Covid-19 is by doing $3 \mathrm{~W}$ (wear mask, wash hands, wait until others distanced at 1-2 meters) which is recommended by WHO. However, based on Task Force (SatGas) data, from health protocol disciplinary monitoring shows that the level of community compliance with $3 \mathrm{~W}$ health protocols is still not satisfactory yet. The health protocol disciplinary monitoring, which has been done since November 18, 2020 shows a trend of decreasing individual compliance in wearing masks, maintaining distance, and avoiding crowds. Non- compliance in implementing this health protocol also occurs in the city of Surabaya, especially in Pucang Market. Based on the results of observations at Pucang Market, there are still many buyers did not wear masks, keep their distance, and did wash their hands intensively. The purpose of this community service is to socialize and make the community (buyers and sellers in Pucang Market) understand the ways to prevent Covid-

19 transmission and understand the urgency of implementing 3W in Pucang Market. The method to achieve those purpose is distributing masks and socialization by sticking posters and distributing flyers containing education to prevent Covid-19 transmission with $3 \mathrm{~W}$. The result of this community service was the realization of distribution of 350 masks, sticking posters and distribution flyers containing education to prevent Covid-

19 transmission with $3 \mathrm{~W}$ which received a positive response from both market management and market sellers and buyers that shown with their enthusiasm to read immediately and photograph the posters and wore the masks that was distributed to them. Socialization of $3 \mathrm{~W}$ in this market is very important because the market is a fertile place to transmit the Corona Virus because of its crowded conditions. By socializing information about prevention methods and the importance of implementing health protocols $(3 \mathrm{~W})$ in this markets, sellers and buyers can prevent the transmission of covid19
\end{abstract}

Keywords : 3W, Covid-19 Prevention, Socialization 


\begin{abstract}
Abstrak
Covid-19 menyebar dengan sangat pesat dan masif dalam waktu singkat. Dalam kurun waktu 1 tahun, virus ini mampu menginfeksi 233 negara di dunia. Oleh karena itu perlu dilakukan serangkaian upaya untuk meminimalisir penyebaran Covid-19. Salah satu cara yang dapat dilakukan untuk meminimalisir penyebaran Covid-19 adalah dengan melakukan 3M (memakai masker, menjaga jarak, dan mencuci tangan) sebagaimana yang direkomendasikan oleh WHO. Namun, berdasarkan data Satuan Tugas Pemantauan Kedisiplinan Protokol Kesehatan menunjukkan bahwa tingkat kepatuhan masyarakat terhadap protokol kesehatan $3 \mathrm{M}$ masih belum memuaskan. Pemantauan kedisiplinan protokol yang dilakukan sejak 18 November 2020 ini memperlihatkan tren penurunan kepatuhan individu dalam memakai masker, menjaga jarak dan menghindari kerumunan. Ketidakpatuhan dalam menerapkan protokol kesehatan ini juga terjadi di kota Surabaya, salah satunya di Pasar Pucang. Berdasarkan hasil observasi di Pasar Pucang, masih banyak pedagang maupun pembeli yang tidak memakai masker, tidak menjaga jarak dan tidak mencuci tangan secara intens. Tujuan dari pengabdian ini adalah untuk memasyarakatkan atau menjadikan masyarakat (pembeli dan penjual di pasar pucang) mengenal dan memahami cara untuk mencegah penularan Covid-19 serta menjadikan masyarakat memahami urgensi penerapan $3 \mathrm{M}$ di Pasar Pucang. Adapun metode yang digunakan adalah dengan pembagian masker dan sosialisasi dengan penempelan poster dan pembagian flyer yang berisi edukasi pencegahan penularan Covid-19 melalui 3M. Hasil dari kegiatan pengabdian ini adalah terealisasinya pembagian 350 masker serta penempelan poster dan pembagian flyer edukasi pencegahan Covid-19 dengan $3 \mathrm{M}$ yang mendapatkan respons yang positif baik dari manajemen pasar dan pedagang pasar maupun pembeli, ditunjukkan dengan antusiasme mereka untuk langsung membaca dan memfoto poster yang telah ditempelkan dan menggunakan masker yang telah dibagikan. Sosialisasi $3 \mathrm{M}$ di pasar ini sangat penting karena pasar menjadi tempat yang cukup subur untuk menularkan Virus Corona mengingat kondisinya yang ramai bahkan sesak pengunjung. Dengan sosialisasi terkait cara pencegahan dan pentingnya menerapkan protokol kesehatan $(3 \mathrm{M})$ di pasar, pedagang dan pembeli dapat mencegah penularan covid-19.
\end{abstract}

Kata Kunci : 3M , Pencegahan Penularan Covid-19, Sosialisasi

\title{
PENDAHULUAN
}

Covid-19 merupakan keluarga besar virus yang menyebabkan penyakit pada manusia dan hewan. Pada manusia biasanya menyebabkan penyakit infeksi saluran pernapasan, mulai flu biasa hingga penyakit yang serius seperti Middle East Respiratory Syndrome (MERS) dan Sindrom Pernafasan Akut Berat atau Severe Acute Respiratory Syndrome (SARS). Coronavirus jenis baru yang ditemukan pada manusia sejak kejadian luar biasa muncul di Wuhan Cina, pada Desember 2019, kemudian diberi nama Severe Acute Respiratory Syndrome Coronavirus 2 (SARS-COV2), dan menyebabkan penyakit Coronavirus Disease-2019 (COVID-19). COVID-19 memiliki nilai CFR (tingkat kematian akibat virus) kurang dari $5 \%$. Nilai CFR ini merupakan nilai yang cukup rendah apabila dibandingkan dengan SARS (Kemenkes, 2021). WHO sebagai Badan Kesehatan Dunia menilai risiko akibat virus tersebut termasuk kategori tinggi di tingkat global dan menetapkan status Public Health Emergency of International Concern (PHEIC) sejak tanggal 30 Januari 2020 (World Health Organization, 2020).Meskipun tingkat kematian akibat Covid-19 cukup rendah, namun virus ini mengalami penyebaran yang sangat cepat dan luas mencakup beberapa negara di dunia. Berdasarkan data yang dirilis oleh WHO pada tanggal 11 Februari 2021, kasus terkonfirmasi positif Covid-19 sudah mencapai 107.166.785 kasus yang mencakup 233 negara di dunia. Salah satu dari beberapa negara yang terpapar Covid-19 adalah 
Indonesia. Penyebaran Covid-19 di Indonesia saat ini sudah semakin meningkat dan meluas lintas wilayah dan lintas negara yang ditandai dengan peningkatan jumlah kasus dan penyebarannya. Pada 11

Februari 2021, Indonesia melalui laman Satgas Penanganan Covid-19 (https://covid19.go.id) menunjukkan jumlah kasus terkonfirmasi positif Covid-19 sebesar 1.183.555 dan sebesar 32.167 kasus kematian. Laman ini juga menunjukkan bahwa Covid-19 telah menyebar di 96,89\% wilayah Indonesia. Data tersebut, menunjukkan bahwa Covid-19 dapat menyebar secara masif dalam waktu singkat, kurang dari 1 tahun sejak diumumkan kasus pertama di Indonesia pada bulan Maret 2020 .

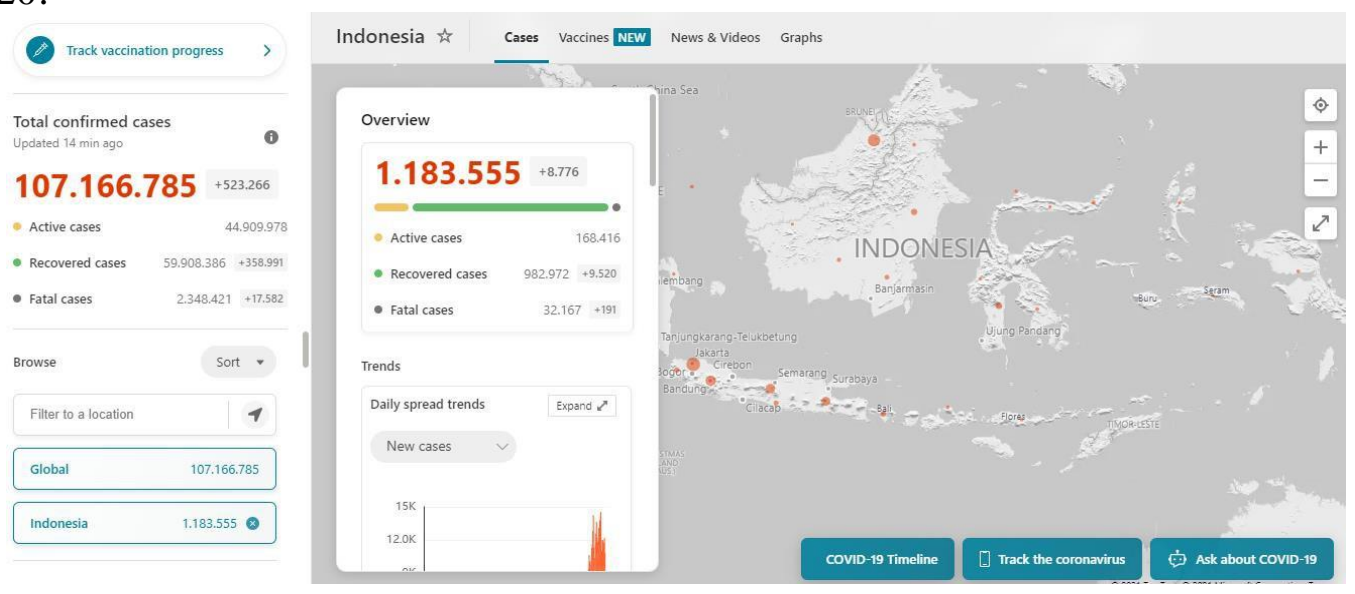

Gambar 1.1 Data kasus terkonfirmasi Covid-19 Global dan Indonesia

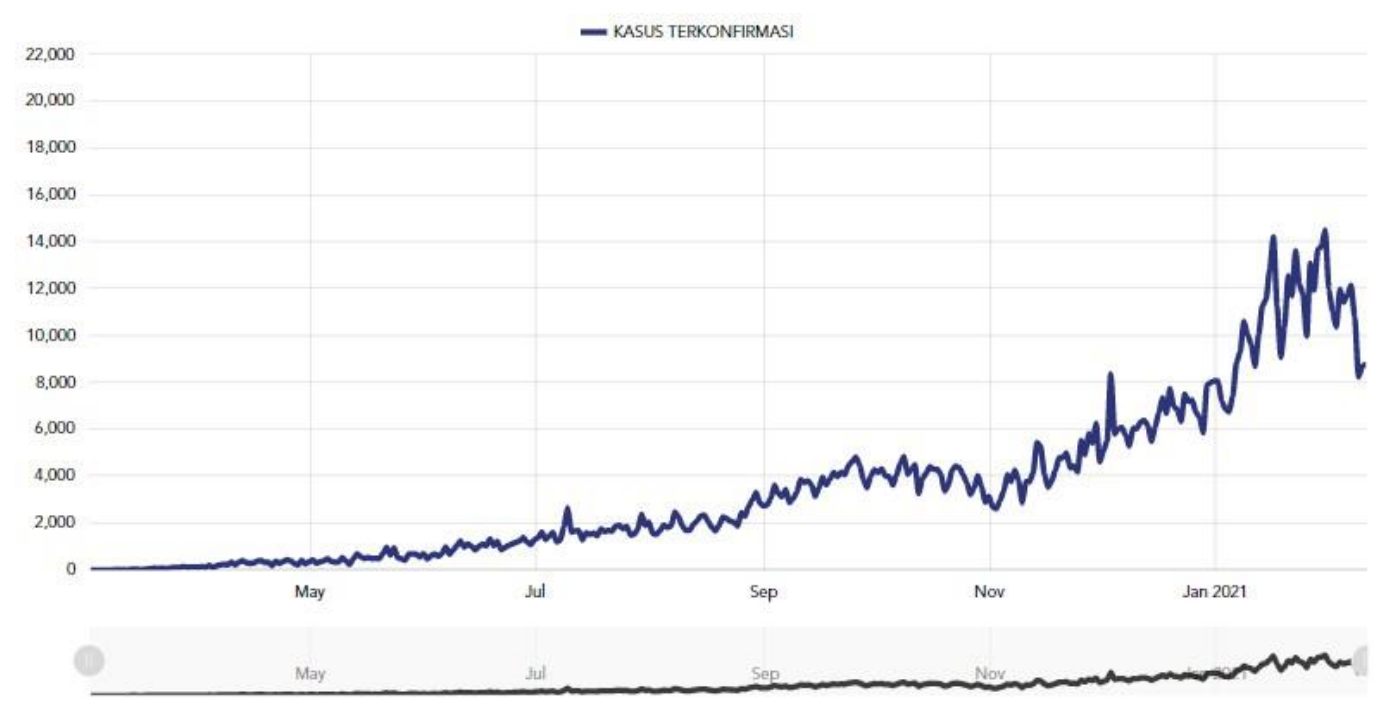

\section{Gambar 1.2 Data perkembangan kasus terkonfirmasi Covid-19 di Indonesia}

Penyebaran Covid-19 yang masif dalam waktu singkat ini dapat terjadi karena penularan virus ini cukup mudah, yaitu melalui tetesan kecil (droplet) dari hidung atau mulut penderita Covid-19 pada saat batuk atau bersin. Droplet tersebut kemudian jatuh pada benda di sekitarnya. Kemudian jika ada orang lain menyentuh benda yang sudah terkontaminasi dengan droplet tersebut, lalu orang itu menyentuh mata, hidung atau mulut 
(segitiga wajah), maka orang itu dapat terinfeksi COVID-19. Atau bisa juga seseorang terinfeksi COVID-19 ketika tanpa sengaja menghirup droplet dari penderita (Kemenkes, 2021). Dari cara penularan Covid-19 tersebut, dapat diketahui bahwa virus ini sangat mudah menular sehingga perlu dilakukan berbagai upaya untuk mencegah penularannya. Pemerintah Indonesia menetapkan langkah-langkah dan upaya untuk mengantisipasi penyebaran dan mencegah memburuknya situasi pandemi covid-19, diantaranya adalah dengan mensosialisasikan gerakan 3M (Menjaga jarak minimal 1 meter, Mencuci tangan dengan sabun dan air mengalir, serta Menggunakan masker menutupi seluruh area hidung sampai dagu bagian bawah). Berdasarkan hasil survei perilaku masyarakat di masa pandemi Covid-19 (7-14 September 2020) yang dilakukan oleh Badan Pusat Statistik (BPS), menyatakan bahwa masih banyak masyarakat yang tidak menerapkan protokol kesehatan. Hal tersebut disebabkan oleh: 1. Tidak ada sanksi jika tidak menerapkan protokol kesehatan; 2. Tidak ada kejadian penderita Covid-19 di lingkungan sekitar; 3. Pekerjaan menjadi sulit jika harus menerapkan protokol kesehatan; 4. Harga masker, face-shield, hand sanitizer atau APD lain cenderung mahal; 5. Mengikuti orang lain; 6. Aparat atau pimpinan tidak memberi contoh; dan 7. Lainnya Laras Sekarasih Ph.D. (www.ui.ac.id, 2020) menyebutkan bahwa secara faktual tampak banyak anggota masyarakat yang mengabaikan protokol kesehatan, terlebih lagi saat upaya pembatasan mulai dilonggarkan yang disebabkan beberapa hal meliputi: persepsi risiko yang rendah, bias optimisme, ketidakpedulian yang disengaja, dan lain-lain. Selain itu, dilakukan pemantauan kedisiplinan protokol pada 18 November 2020 yang memperlihatkan bahwa terjadi tren penurunan kepatuhan individu dalam memakai masker, menjaga jarak dan menghindari kerumunan (Tim Komunikasi Komite Penanganan Corona Virus Disease 2019 (Covid-19) dan Pemulihan Ekonomi Nasional, 2020). Ketidakpatuhan dalam menerapkan protokol kesehatan ini terjadi di kota Surabaya, salah satunya di Pasar Pucang. Pasar Pucang merupakan salah satu pasar tradisional di Surabaya yang menjual berbagai kebutuhan masyarakat seperti sandang, pangan dan kebutuhan lainnya. Lokasinya berada di jalan Pucang Anom Surabaya Selatan. Selain menjual sebagai kebutuhan pokok, pasar ini juga dikenal sebagai pasar buah. Berdasarkan hasil observasi, masih banyak ditemui pedagang maupun pembeli yang tidak memakai masker, tidak menjaga jarak dan tidak mencuci tangan secara intens. Pedagang dan pembeli mengalami kesulitan dalam menjaga jarak 1-2 meter karena jarak antar toko satu dengan toko yang lain cukup dekat/rapat, sehingga menjadikan pembeli saling berdekatan ketika hendak melakukan transaksi. Padahal, di masa pandemi, pasar menjadi tempat yang cukup efektif untuk menularkan Virus Corona mengingat kondisinya yang ramai bahkan sesak oleh pedagang dan pembeli. Oleh karena itu, sangat penting untuk menerapkan gerakan 3M sebagai upaya untuk pencegahan penularan Covid-19 melalui program yang telah disusun oleh Kelompok 137 KKN BBM 63, Universitas Airlangga. 


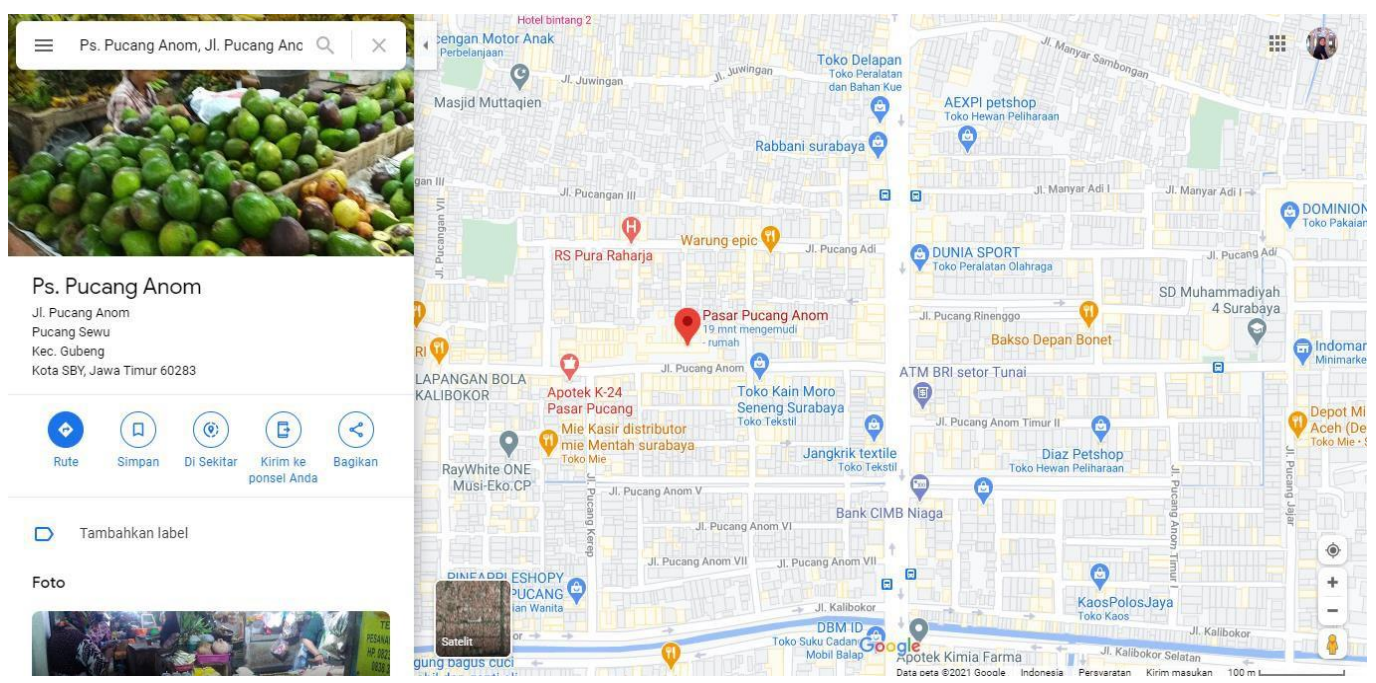

Gambar 1.3 Peta lokasi kegiatan pengabdian masyarakat

\section{METODE PENGABDIAN MASYARAKAT}

Untuk bisa mencapai tujuan untuk memasyarakatkan atau menjadikan masyarakat (pembeli dan penjual di pasar pucang) memahami cara untuk mencegah penularan covid-19 dengan 3M (memakai masker, menjaga jarak, dan mencuci tangan) di keramaian, khususnya di Pasar Pucang dan meningkatkan kesadaran pembeli dan pedagang di Pasar Pucang pentingnya penerapan protokol kesehatan dengan baik dan benar, maka metode yang kami gunakan untuk merealisasikan tujuan pengabdian tersebut adalah dengan melakukan pembagian 350 masker serta melakukan sosialisasi 3M kepada penjual dan pembeli di Pasar Pucang dengan penempelan poster dan pembagian flyer.

Program sosialisasi pencegahan Covid-19 yang dilakukan di Pasar Pucang ini dilakukan dengan melalui beberapa tahapan yang dimulai dengan melakukan koordinasi dengan pihak manajemen pasar terkait sistematika pelaksanaan sosialisasi pembagian flyer dan penempelan poster serta penyerahan 350 masker medis. Untuk bisa lebih termanajemen dalam pembagian flyer dan masker maka hal ini diserahkan kepada tim manajemen Pasar Pucang untuk kemudian dibagikan kepada pedagang dan pembeli di Pasar Pucang. Selain itu, sosialisasi pencegahan Covid-19 ini juga dilakukan dengan menempelkan poster yang berisikan himbauan terkait untuk tetap mengikuti protokol kesehatan dengan 3M yang kami lakukan di tempat-tempat strategis agar lebih mudah dilihat dan dibaca oleh banyak pedagang maupun pembeli yang lalu lalang.

Agar tujuan sosialisasi untuk pencegahan penularan covid-19 di Pasar Pucang ini dapat terukur keberhasilannya, maka untuk mengukurnya kami menggunakan alat ukur berupa sikap pedagang dan pembeli di Pasar Pucang setelah dilakukannya sosialisasi covid-19 yaitu feedback positif oleh pedagang dan pembeli saat sosialisasi dilakukan dan tingkat kepatuhan mereka di Pasar Pucang dalam menerapkan 3M baik memakai masker, menjaga jarak maupun mencuci tangan secara berkala setelah sosialisasi 3M ini dilakukan. Jika dengan sosialisasi $3 \mathrm{M}$ dan pembagian masker ini mendapatkan feedback positif oleh penjual dan pembeli di Pasar Pucang dengan membaca dan memahami poster yang ditempel dan flyer yang dibagikan, serta meningkatnya 
kepatuhan masyarakat untuk memakai masker, menjaga jarak minimal 1 meter, dan mencuci tangan secara berkala, maka sosialisasi ini dinilai berhasil. Untuk mengukurnya adalah dengan melakukan observasi pedagang dan pembeli di Pasar Pucang setelah sosialisasi dilakukan

\section{HASIL DAN PEMBAHASAN}

Berdasarkan latar belakang masalah yang dipaparkan, beberapa permasalahan yang terjadi di Pasar Pucang terkait penerapan protokol kesehatan diantaranya: (1) Kurangnya kesadaran pedagang dan pembeli dalam menerapkan 3M, di mana masih banyak ditemui pedagang maupun pembeli yang tidak memakai masker, tidak menjaga jarak dan tidak mencuci tangan. (2) Pedagang dan pembeli mengalami kesulitan menjaga jarak 1-2 meter karena toko satu dengan toko yang lain berdekatan, sehingga pembeli saling berdekatan ketika hendak melakukan transaksi. Berkaitan dengan hal tersebut, Kelompok 137 KKN BBM 63 Universitas Airlangga melaksanakan program Sosialisasi 3M dan Pembagian Masker. Dalam mewujudkan atau mencapai program tersebut secara efektif dan efisien, diperlukan cara dan pendekatan yang strategis. Cara ini sering disebut "strategi", yaitu teknik atau cara bagaimana mencapai atau mewujudkan suatu program tersebut secara berhasil guna dan berdaya guna (Soekidjo Notoatmodjo, 2005). Strategi yang digunakan dalam menjalankan program ini adalah pengabdian masyarakat, di mana sasaran utamanya adalah pedagang dan pembeli di Pasar Pucang. Tujuan dari program ini adalah untuk memasyarakatkan atau menjadikan masyarakat sasaran (pembeli dan pedagang di pasar pucang) mengenal dan memahami cara untuk mencegah penularan Covid-19 serta menjadikan sasaran memahami urgensi penerapan 3M di keramaian, khususnya di Pasar Pucang. Selain itu, program ini bertujuan untuk meningkatkan respons afektif dan kesadaran pembeli dan pedagang di Pasar Pucang terhadap penerapan protokol kesehatan dengan baik dan benar. Sehingga pedagang maupun pembeli di Pasar Pucang mampu memiliki sikap yang baik dalam mengantisipasi penyebaran dan mencegah memburuknya situasi pandemi Covid-19.

Dalam upaya meningkatkan kesadaran sasaran yang berkaitan dengan pentingnya penerapan protokol kesehatan dengan baik dan benar di masa pandemi dapat dilihat dengan menggunakan penerapan teori Health Belief Model (HBM), beberapa komponen HBM sebagai berikut:

\section{Perceived Susceptibility}

Kerentanan yang dirasakan (Perceived susceptibility) oleh sasaran yaitu keyakinan pada diri seseorang terkait dengan kerentanan dirinya yang akan memberikan dampak pada kesehatan sehingga akan mendorong seseorang untuk perubahan pada perilaku yang lebih sehat, dalam artian sasaran memiliki persepsi bahwa mereka berisiko atau rentan apabila ia tidak patuh dalam menerapkan protokol kesehatan di masa pandemi Covid-19.

Perceived Severity

Perceived severity adalah keyakinan individu akan keparahan apabila tidak menerapkan protokol kesehatan dengan baik dan benar serta dampak dari ketidakpatuhan tersebut.

Perceived Benefits

Manfaat yang dirasakan oleh sasaran setelah melakukan suatu tindakan pencegahan melalui penerapan protokol kesehatan di masa-masa pandemi Covid-19 sehingga sasaran akan memiliki keyakinan jika menggunakan masker, mencuci tangan, dan 
menjaga jarak akan memberikan banyak manfaat, diantaranya adalah dapat mencegah penularan Covid-19 atau terhindar dari Covid-19, dapat menurunkan angka kasus terkonfirmasi, menjaga atau memelihara derajat kesehatan agar tetap tinggi. Dengan demikian sasaran akan memiliki kepatuhan sebagai bentuk pencegahan terhadap penyakit Covid-19 dengan patuh terhadap penerapan protokol kesehatan.

\section{Perceived Barriers}

Pada dasarnya setiap sasaran memiliki hambatan dalam mematuhi protokol kesehatan seperti halnya toko atau kios pedagang dengan pedagang lainnya terlalu dekat, pembeli yang tidak menjaga jarak, peletakan tempat cuci tangan yang kurang strategis, dan tidak ada sanksi apabila tidak menerapkan protokol kesehatan. Hambatan-hambatan tersebut menjadikan sasaran tidak patuh dalam menerapkan protokol kesehatan. Semakin banyak hambatan yang dirasakan sasaran dalam mematuhi protokol kesehatan, maka ketidakpatuhan sasaran tersebut akan berisiko meningkatkan jumlah kasus terkonfirmasi positif di Indonesia dan meningkatkan risiko penyebaran Covid-19 khususnya terjadi pada kluster pasar.

\section{Cues to action}

Adanya dorongan untuk melakukan upaya kesehatan yang berasal dari kesadaran diri atau dorongan orang lain; misalnya adanya aturan atau peraturan khusus dari pihak manajemen Pasar Pucang, pengaruh dari adanya media penyuluhan offline seperti poster, serta adanya edukasi yang bersumber dari pedoman-pedoman penanganan Covid-19.

\section{Self Efficacy}

Sasaran merasa percaya diri dengan menerapkan protokol kesehatan dan mengetahui bahwa dampak ketidakpatuhan protokol kesehatan di masa pandemi Covid-19 akan menimbulkan bahaya.

Teori Health Belief Model dapat digunakan untuk mempelajari dan mempromosikan peningkatan pelayanan kesehatan dalam hal ini berkaitan dengan penerapan protokol kesehatan. Sehingga, kelompok 137 KKN BBM 63 melaksanakan program pengabdian "Sosialisasi 3M dan Pembagian Masker" yang diwujudkan dalam beberapa kegiatan.

Program sosialisasi pencegahan Covid-19 yang dilakukan di Pasar Pucang terlebih dahulu dimulai dengan melakukan koordinasi dengan pihak manajemen atau pengelola pasar terkait dengan sistematika pelaksanaan sosialisasi. Pada tanggal 7 Februari 2021, kelompok 137 KKN BBM 63 mengunjungi kantor manajemen Pasar Pucang dengan tujuan untuk menyerahkan 350 masker medis yang nantinya akan dibagikan oleh pengelola atau tim manajemen Pasar Pucang kepada pedagang pasar. Selain masker medis, kegiatan sosialisasi lainnya dilakukan dalam bentuk membagikan flyer untuk pedagang melalui manajemen Pasar Pucang.

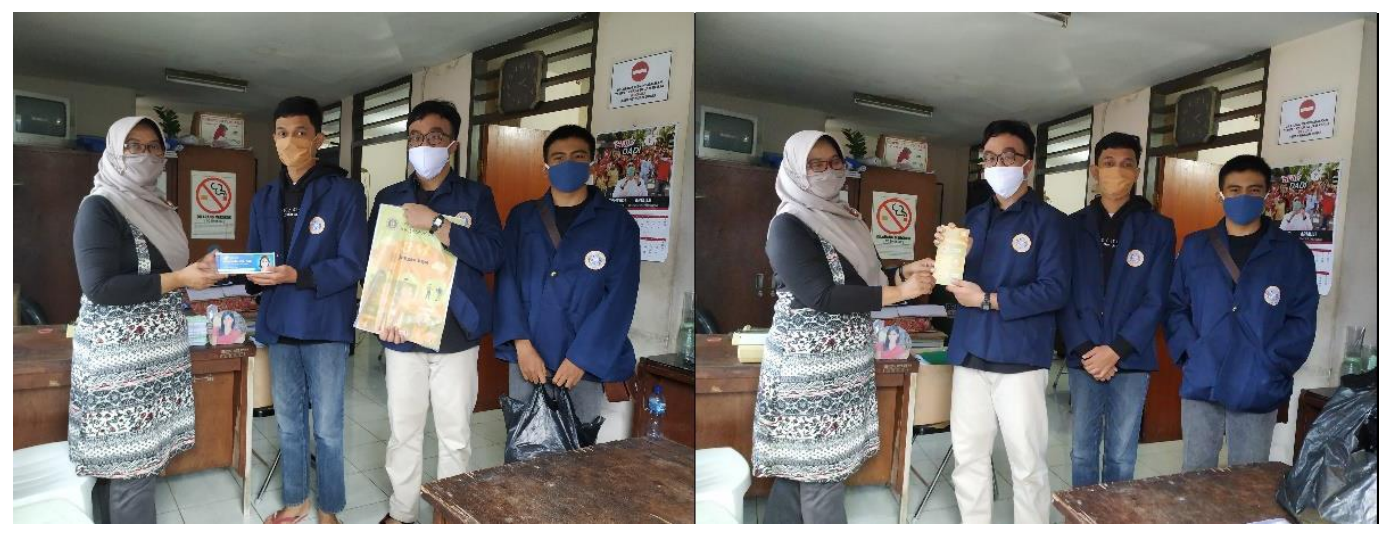




\section{Gambar 1 Penyerahan masker dan flyer kepada manajemen Pasar Pucang untuk dibagikan kepada pedagang pasar}

Selanjutnya, sosialisasi pencegahan Covid-19 di Pasar Pucang dilakukan dengan menempelkan poster yang berisikan himbauan kepada seluruh pedagang dan pembeli untuk lawan Covid-19 dengan tetap mengikuti protokol kesehatan dengan cara 3M yaitu mencuci tangan menggunakan sabun, menjaga jarak, dan memakai masker. Penempelan poster dilakukan pada tempat-tempat yang strategis di lingkungan pasar sehingga dapat menarik perhatian dan menjadi pengingat bagi pedagang pasar dan pembeli untuk selalu menerapkan protokol kesehatan ketika beraktivitas dan berinteraksi di Pasar. Kegiatan ini mendapatkan respons yang positif baik dari manajemen pasar dan pedagang pasar maupun pembeli, ditunjukkan dengan antusias mereka dimana langsung membaca dan memfoto poster yang telah ditempelkan.
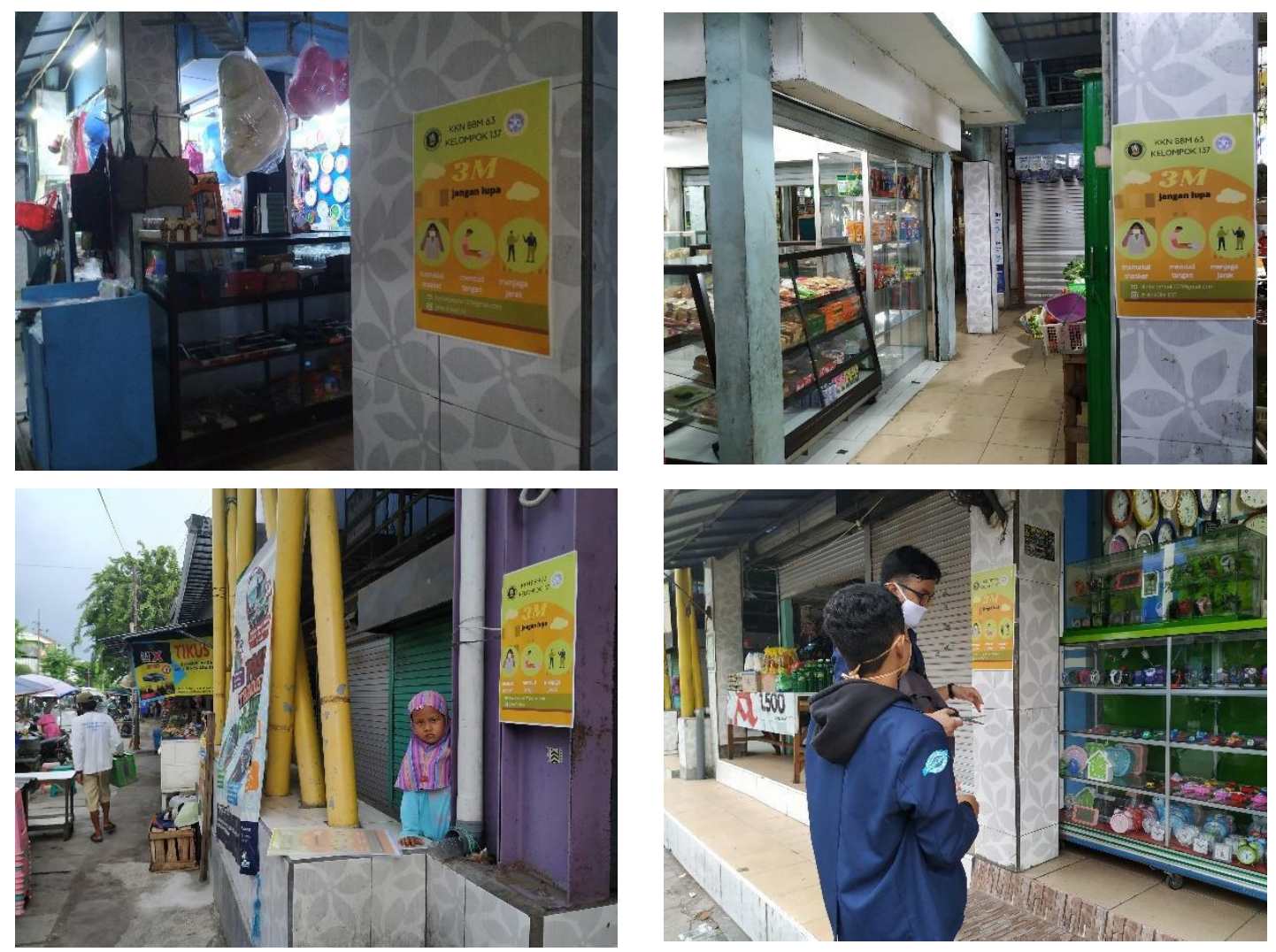

Gambar 2 Proses penempelan poster sebagai media sosialisasi 3M

Hasil yang diharapkan dari program "Sosialisasi 3M dan Pembagian Masker di Pasar Pucang" adalah meningkatnya kesadaran dan pemahaman akan pentingnya seluruh masyarakat sasaran (pedagang pasar dan pembeli) untuk menerapkan protokol kesehatan dan patuh menjalankan protokol kesehatan. Dengan demikian, dapat mengurangi penyebaran virus khususnya di pasar Pucang dan mengalami penurunan jumlah kasus terkonfirmasi Covid-19 yang berawal dari penularan atau klaster pasar.

\section{KESIMPULAN DAN SARAN}

Sosialisasi 3M dan pembagian masker dilakukan di Pasar Pucang Surabaya sebagai tempat umum yang belum optimal dalam menerapkan protokol kesehatan. Teknis pelaksanaan 
sosialisasi 3M dilakukan dengan cara membagikan flyer untuk pedagang melalui manajemen Pasar Pucang dan menempelkan poster $3 \mathrm{M}$ pada tempat yang strategis sehingga dapat menarik perhatian dan menjadi pengingat bagi pedagang pasar dan pembeli untuk selalu menerapkan protokol kesehatan ketika beraktivitas dan berinteraksi di Pasar. Sedangkan teknis pembagian masker dilakukan dengan cara memberi 350 masker medis kepada manajemen pasar pucang untuk dibagikan kepada pedagang pasar. Kegiatan sosialisasi 3M dan pembagian masker di Pasar Pucang Surabaya disambut positif baik oleh manajemen pasar dan pedagang pasar maupun pembeli. Kegiatan ini dilakukan dengan tujuan untuk meningkatkan kesadaran dan pemahaman masyarakat sasaran (pedagang pasar dan pembeli) terkait pentingnya menerapkan protokol kesehatan dan juga bertujuan agar masyarakat sasaran mematuhi protokol kesehatan sebagai upaya mencegah penularan Covid-19 di pasar.

Saran yang dapat kami berikan untuk program pencegahan penularan Covid-19 ini adalah program sosialisasi dan pembagian masker hendaknya dibarengi dengan kontrol/pengawasan intensif terhadap kepatuhan masyarakat sasaran (pembeli dan pedagang pasar) dalam menerapkan protokol kesehatan. Pengawasan/kontrol ini diperlukan karena disadari bahwa untuk menjadikan masyarakat sasaran mematuhi protokol kesehatan tidak cukup dengan sekali atau dua kali sosialisasi, melainkan dibutuhkan upaya yang lebih intens untuk memastikan masyarakat sasaran benar-benar mematuhi protokol kesehatan.

\section{DAFTAR PUSTAKA}

https://covid19.go.id/p/berita/kepatuhan-masyarakat-terhadap-protokol kesehatan- harus-ditingkatkan diakses pada tanggal 8 Februari 2021

https://covid19.go.id diakses pada tanggal 8 Februari 2021 https://covid19.go.id/petasebaran-covid19 diakses pada tanggal 8 Februari 2021

http://disperdagin.surabaya.go.id/bahanpokok/profilpasar/detail-pasar/PAS002 diakses pada tanggal 8 Februari 2021

https://www.bps.go.id/ diakses pada tanggal 8 Februari 2021

https://www.kemkes.go.id/folder/view/full-content/structure-faq.html diakses pada tanggal 8 Februari 2021

https://www.ui.ac.id/ui-rekomendasikan-kebijakan-untuk-tingkatkan- diakses pada tanggal 8 Februari 2021

kepatuhanterhadap-protokol-kesehatan-dan-cegah-stigma-covid-19/ diakses pada tanggal 11 Februari 2021

https://www.who.int/emergencies/diseases/novel-coronavirus-2019 diakses pada tanggal 8 Februari 2021

Notoatmodjo, Soekidjo. 2005. Promosi Kesehatan: Teori dan Aplikasi. Jakarta: PT.Rineka Cipta

Syapitri, Henny, Laura Mariati Siregar, dan Frida Liharis Saragih. 2020. "Pencegahan Penularan Covid-19 Melalui Sosialisasi Dan Pembagian Masker Di Pasar Pringgan Medan." Jurnal Kreativitas Pengabdian Kepada Masyarakat (Pkm), 2020, 3.2: 422-29. 